\title{
Toksisitas Subletal Limbah Cair Batik Hasil Biosorpsi terhadap Hematokrit Ikan Mas (Cyprinus carpio)
}

\author{
Nur Hidayati, Sri Lestari*, Eko Setio Wibowo
}

\author{
Fakultas Biologi, Universitas Jenderal Soedirman \\ Jalan dr. Suparno 63 Purwokerto 53122 \\ *Email: srilestari.bio@ unsoed.ac.id
}

\begin{abstract}
Rekam Jejak Artikel:
Diterima : 08/08/2019

Disetujui : 18/10/2019
\end{abstract}

\begin{abstract}
Research on the hematocrit value of fish exposed to batik wastewater resulted from biosorption process needed because the blood is one indicator of contaminants present that entering the fish body. This research aims to determine the effects of batik wastewater resulted from biosorption process exposure on Carp (Cyprinus carpio) hematocrit value. The treatments are batik wastewater resulted from biosorption process with different concentrations, i.e $0 ; 1.32 ; 2.64$ and $3.96 \% \mathrm{v}^{-1} \mathrm{v}^{-1}$ The carp maintained for 7 days and the blood was taken in the 8 days. Measured variables was hematocrit value. The result shows that the highest of the hematocrit in $0 \% \mathrm{v} / \mathrm{v}^{-1}$ concentration was $31.67 \pm 1.49 \%$ while the lowest in $3.96 \% \mathrm{v}^{-1} \mathrm{v}^{-1}$ concentration was $26.00 \pm 1.15$ $\%$.The conclusion, that batik wastewater resulted from biosorption process induced a significant increase the hematocrit value.

Keyword: batik wastewater, biosorpstion, hematocrite, carp
\end{abstract}

\begin{abstract}
Abstrak
Nilai hematkrit ian dapat digunakn indkator cemaran lmba cairan batk hasl biosorpsi. Tujuan penelitian adalah untuk mengetahui pengaruh pemaparan limbah cair batik hasil biosorpsi terhadap nilai hematokrit Ikan Mas (Cyrinus carpio). Perlakuan berupa konsentrasi limbah cair batik hasil biosorpsi yang terdiri dari $0 ; 1,32 ; 2,64$ dan $3,96 \% \mathrm{v} \cdot \mathrm{v}^{-1}$. Ikan dipelihara selama 7 hari dan sampel darah diambil pada hari ke-8. Parameter yang diukur adalah nilai hematokrit. Hasil penelitian menunjukkan nilai hematokrit tertinggi pada perlakuan $0 \%{\mathrm{v} . \mathrm{v}^{-1}}^{-1}$ sebesar $31,67 \pm 1,49 \%$ dan terendah pada konsentrasi $3,96 \% \mathrm{v}^{-1} \mathrm{v}^{-1}$ sebesar $26,00 \pm 1,15 \%$. Kesimpulan penelitian yaitu limbah cair batik hasil biosorpsi berefek terhadap peningkatan nilai hematokrit.

Kata kunci: biosorpsi, ikan mas, limbah cair batik, hematokrit
\end{abstract}

\section{PENDAHULUAN}

Sentra Batik Sokaraja merupakan kumpulan dari beberapa industri batik rumahan. Limbah cair yang dihasilkan langsung dibuang tanpa pengolahan ke Kali Wangan sehingga menyebabkan pencemaran. Masyarakat memanfaatkan Kali Wangan sebagai sumber irigasi dan aktivitas lain, seperti mandi, mencuci dan budidaya ikan. Pencemaran limbah cair batik di kali Wangan berdampak terhadap biota yang hidup di dalamnya dan manusia yang mengkonsumsinya. Kadar Karbondioksida terlarut (COD), oksigen terlarut (BOD), dan TSS air Kali Wangan telah melampaui baku mutu lingkungan berturut-turut, yaitu 672,78, 540,42, dan 540,13 mg.. - $^{-1}$, sementara untuk parameter logam berat yang melebihi baku mutu adalah krom sebesar 0,231 mg.L ${ }^{-1}$ (Lestari et al., 2015).

Kandungan logam berat pada limbah cair batik dapat dipisahkan melalui proses biosorpsi. Biosorpsi merupakan proses pemisahan logam berat dari limbah cair batik menggunakan organisme mati atau yang diinaktifkan (Okuo et al., 2006). Proses biosorpsi memiliki keunggulan, yaitu bersifat efisien, murah, aman, dan memiliki laju penyerapan relatif tinggi (Joshi, 2017). Penggunaan biosorben campuran antara jerami dan limbah baglog Pleuratus ostreatus dengan perbandingan 3:1 yang dikemas dengan kantung teh celup termodifikasi telah menunjukkan penurunan kadar $\mathrm{Cr}$ sebesar $75,72 \%$ dari konsentrasi awal 0,0219 menjadi 0,0016 mg.L. $\mathrm{L}^{-1}$ (Lestari et al., 2019). Hal tersebut mengindikasikan bahwa masih ada kandungan krom yang tersisa limbah cair batik hasil biosorpsi, sehingga perlu dilakukan uji toksisitas terhadap ikan sebelum dibuang ke lingkungan. Pemaparan $\mathrm{Cr}$ pada ikan berdampak buruk, mulai dari aspek fisiologi, histologi, enzimatis, sampai aspek genetik (Velma et al., 2009).

Nilai LC $_{50} 96$ jam limbah batik cair hasil biosorpsi terhadap Ikan Nila sebesar 52,876 ppm (Lestari et al., 2017),. Nilai LC $_{50}$ tersebut tergolong kurang toksik (Casarett \& Klaassen, 2008). Namun, uji toksisitas subletal terhadap insang menunjukkan kerusakan tingkat dua yaitu terjadinya hiperplasia sedangkan terhadap hepar menunjukkan adanya edema pada sel hepatosit (Lestari, 2018). Riset 
tentang toksisitas subletal limbah cair batik hasil biosorpsi terhadap nilai hematokrit darah. Ikan Mas (Cyprinus carpio) belum pernah dilakukan. Ikan mas merupakan ikan yang banyak dibudidayakan oleh masyarakat di sekitar Kali Wangan. Tujuan penelitian adalah untuk mengetahui pengaruh pemaparan dan konsentrasi limbah cair batik hasil biosorpsi yang paling berpengaruh terhadap nilai hematokrit Ikan Mas sehingga dapat dijadikan acuhan mengenai kualitas biota konsumsi.

\section{MATERI DAN METODE}

Penelitian ini telah dilaksanakan di Stasiun Percobaan, Laboratorium Mikrobiologi dan Laboratorium Fisiologi Hewan Fakultas Biologi, Universitas Jenderal Soedirman, Purwokerto, Jawa Tengah. Metode yang digunakan dalam penelitian adalah eksperimental dengan rancangan acak lengkap pola searah menggunakan empat perlakuan dengan enam kali ulangan. Penentuan konsentrasi berdasarkan nilai $\mathrm{LC}_{50} 96$ jam limbah batik hasil biosorpsi terhadap ikan Nila, yaitu 5,28 \% v.v ${ }^{-1}$. Konsentrasi yang diujikan adalah kontrol (0 \% v.v $\left.{ }^{1}\right) ; 25 \%$ nilai $\mathrm{LC}_{50}\left(1,32 \%{\mathrm{v} . \mathrm{v}^{-1}}^{2}\right) ; 50 \%$ nilai $\mathrm{LC}_{50}$ $\left(2,64 \% \mathrm{v}^{-1} \mathrm{v}^{-1}\right)$ dan $75 \%$ nilai $\mathrm{LC}_{50}\left(3,96 \% \mathrm{v}^{-1} \mathrm{v}^{-1}\right)$.

Variabel bebas penelitian adalah konsentrasi limbah cair batik hasil biosorpsi, sedangkan variabel terikatnya adalah nilai hematokrit $(\%)$ darah Ikan Mas. Parameter pendukung meliputi kualitas air pada media berupa suhu, $\mathrm{pH}$, dan oksigen terlarut. Pengamatan parameter pendukung dilakukan satu kali setiap hari selama 7 hari pemeliharaan.

\section{Persiapan Limbah Cair Batik}

Limbah cair batik diperoleh dari Sentra Batik Sokaraja di Desa Sokaraja Kidul, Kecamatan Sokaraja, Kabupaten Banyumas, Jawa Tengah. Limbah cair batik dibiosorpsi menggunakan campuran jerami padi dan limbah baglog $P$. ostreatus yang dikemas dalam kantung teh celup dengan ukuran $6 \times 6 \mathrm{~cm}$ dan diratakan dengan las plastik. Biosorben ditimbang dengan bobot $300 \mathrm{mg}$ dengan komposisi 3:1. Limbah cair batik sebanyak $100 \mathrm{~mL}$ dimasukkan dalam erlenmeyer $250 \mathrm{~mL}$ dan ditambah 1 buah biosorben. Erlenmeyer ditutup dengan plastik dan dihomogenkan dalam shaker dengan kecepatan $170 \mathrm{rpm}$ pada suhu ruang selama satu jam.

\section{Persiapan Hewan Percobaan}

Hewan uji yang digunakan adalah ikan mas dengan panjang 20-25 cm dan bobot 90-140 g sebanyak 24 ekor. Ikan diperoleh dari pembibitan ikan di Desa Beji, Purwokerto. Ikan diaklimasi selama 7 hari pada bak fiber yang dilengkapi dengan aerator. Air disipon 3 hari sekali. Selama aklimasi ikan diberi pakan pelet yang diberikan pada pagi dan sore hari. Pemberian pakan dilakukan secara adlibitum.

\section{Uji Subletal (Lestari et al., 2018)}

Eksperimen dilakukan secara batch culture menggunakan bak plastik volume $15 \mathrm{~L}$ dengan ukuran $30 \times 25 \times 20 \mathrm{~cm}^{3}$ sebanyak 24 buah. Bak plastik dilengkapi dengan sistem aerator. Setiap bak berisi $10 \mathrm{~L}$ media sesuai dengan perlakukan dan 1 ekor ikan. Ikan Mas dipelihara dengan dipaparkan limbah cair batik hasil biosorpsi selama 7 hari pemaparan. Darah diambil dengan spuit $1 \mathrm{~mL}$ yang telah dibilas dengan EDTA $10 \%$ sebagai antikoagulan. Sampel darah diambil dengan menggunakan teknik punctie cardiac.

\section{Pengukuran Nilai Hematokrit}

Penentuan nilai hematokrit dilakukan menggunakan skala ukur hematokrit. Sampel darah diambil sebanyak $3 / 4$ bagian tabung, lalu salah satu ujung yang berlawanan dengan sampel darah disumbat dengan plastisin. Tabung kemudian di sentrifugasi dengan kecepatan $10.000 \mathrm{rpm}$ selama lima menit. Nilai hematokrit yang diperoleh dibaca dengan skala ukur hematokrit dalam satuan persen (Sari et al., 2016).

\section{Analisis Data}

Data nilai hematokrit dianalisis menggunakan analysis of variance dengan bantuan software SPSS 16.0 pada tingkat kesalahan $5 \%$ untuk mengetahui efek pemaparan limbah cair batik hasil biosorpsi terhadap nilai hematokrit darah Ikan Mas. Hasil dilanjutkan dengan uji Duncan pada tingkat kesalahan yang sama untuk mengetahui konsentrasi yang paling berpengaruh terhadap nilai hematokrit.

\section{HASIL DAN PEMBAHASAN}

Hasil penelitian toksisitas subletal limbah cair batik terhadap nilai hematokrit Ikan Mas selama 7 hari disajikan pada Gambar 1. Berdasarkan Gambar

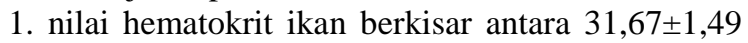

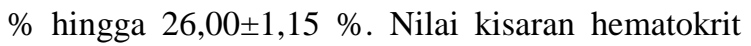
tersebut masih berada di batas normal. Kadar normal hematokrit ikan berkisar antara 20-45\% Hrubec \& Smith (2010). Perlakuan $0 \% \mathrm{v} / \mathrm{v}^{-1}$ memiliki rata-rata tertinggi sebesar $31,67 \pm 1,49 \%$, diikuti dengan perlakuan $1,32 \% \mathrm{v}^{-1} \mathrm{v}^{-1}$ dengan nilai rata-rata sebesar $28,17 \pm 0,90 \%$ dan $2,64 \%{\mathrm{v} . \mathrm{v}^{-1}}^{-1}$

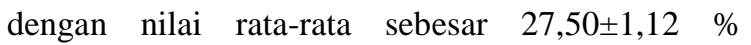
sedangkan terendah $3,96 \%{\mathrm{v} . \mathrm{v}^{-1}}$ sebesar $26,00 \pm 1,15$ $\%$. Nilai hematokrit terjadi berbanding terbalik dengan konsentrasi limbah cair batik hasil biosorpsi yang dipaparkan.

Parameter nilai hematokrit merupakan gambaran dari proporsi besarnya jumlah eritrosit yang terdapat di dalam darah ikan. Nilai hematokrit dapat digunakan untuk menggambarkan fluktuasi jumlah eritrosit dan hemoglobin. Hasil analisis yang menunjukkan terjadinya penurunan nilai hematokrit sesuai dengan penelitian Uttamrao et al. (2017), yang melaporkan bahwa perlakuan sublethal pemaparan logam $\mathrm{Cr}(\mathrm{III})$ dalam bentak kromium klorida dengan konsentrasi $2 \mathrm{mg} . \mathrm{L}^{-1}$ pada $C$. carpio 
telah mempengaruhi parameter hematologis darah berupa penurunan jumlah eritrosit, kadar hemoglobin dan nilai hematokrit.

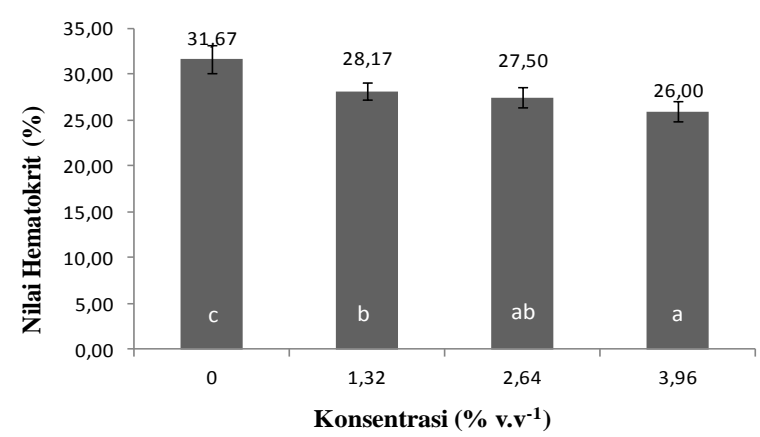

Gambar 1. Histogram jumlah rata-rata nilai hematokrit ikan mas yang terpapar limbah cair batik hasil biosorpsi. Keterangan: Huruf superskipt yang sama menunjukkan tidak ada perbedaan nyata $(\mathrm{P}>0,05)$

Perubahan nilai hematokrit di dalam darah ikan menurut Prayogo et al. (2016), telah menggambarkan terjadinya hipoksia akibat adanya logam berat dalam organ insang. Hal tersebut menyebabkan hemoglobin yang berperan sebagai transpor $\mathrm{CO}_{2}$ dan $\mathrm{O}_{2}$ terhambat, sehingga hemoglobin mengalami kondisi turun naik dan akan diikuti oleh nilai hematokrit. Penelitian sebelumnya terkait kondisi stres diketahui dapat memicu terjadinya gangguan keseimbangan osmotik. Kondisi tersebut dapat menurunkan nilai $\mathrm{pH}$ darah dan meningkatkan volume eritrosit dan selanjutnya akan mempengaruhi nilai hematokrit (Tripathi et al., 2004). Reaksi stres juga diketahui dapat mengarah kepada pelepasan hormon epinefrin menyebabkan premature melepaskan jenis eritrosit immature dan eritrosit rusak dari limfa, sehingga akan mempengaruhi nilai hematokrit (Zaki et al., 2009).

Tabel 1. Parameter kualitas air media pemeliharaan

\begin{tabular}{cccc}
\hline \multirow{2}{*}{$\begin{array}{c}\text { Konsentrasi } \\
\left.\text { v. } \mathrm{v}^{-1}\right)\end{array}$} & $\begin{array}{c}\text { Temperatur } \\
\left({ }^{\circ} \mathrm{C}\right)\end{array}$ & $\mathrm{pH}$ & $\begin{array}{c}\text { DO } \\
\left(\mathrm{mg.L}^{-1}\right)\end{array}$ \\
\hline 0,00 & $23-24$ & 6 & $6,0-7,6$ \\
1,32 & $23-24$ & 6 & $6,4-8,0$ \\
2,64 & $23-24$ & 6 & $7,0-7,8$ \\
3,96 & $23-24$ & 6 & $6,0-7,6$ \\
\hline
\end{tabular}

Berdasarkan hasil analisis statistik, jumlah rata-rata nilai hematokrit berbeda nyata $(p<0,05)$ pada setiap perlakuan konsentrasi terhadap kontrol. Konsentrasi $1,32 \%$ v. $\mathrm{v}^{-1}$ memiliki pengaruh yang sama terhadap nilai hematokrit dengan konsentrasi $2,64 \% \mathrm{v} \cdot \mathrm{v}^{-1}$, sedangkan konsentrasi 2,64 \% v.v $\mathrm{v}^{-1}$ memiliki pengaruh yang sama dengan konsentrasi 3,69 \%v.v ${ }^{-1}$ (Gambar 1). Hal tersebut menunjukkan bahwa konsentrasi berpengaruh terhadap penurunan nilai hematokrit.

Faktor lingkungan perairan ikan hidup atau dipelihara seperti temperatur, $\mathrm{pH}$, dan oksigen terlarut sangat berpengaruh terhadap kondisi fisiologis Ikan. Pada Tabel 1 menunjukkan bahwa kualitas air media pemeliharaan berada dalam kondisi masih normal untuk pemeliharaan atau budidaya ikan, sehingga tidak mempengaruhi perlakuan penelitian.

Hasil pengamatan menunjukkan bahwa temperatur air media pemeliharaan relatif stabil berkisar antara 23-24oC. Kisaran tersebut masih dapat tergolong baik untuk pemeliharaan atau budidaya ikan. Menurut Flajšhans \& Hulata (2007), pada kisaran $23-30^{\circ} \mathrm{C}$ ikan mas masih dapat tumbuh dengan baik. Parameter temperatur dinilai sangat penting karena akan berpengaruh terhadap aktivitas metabolik dan tingkah laku organisme. Ikan yang dipelihara pada temperatur dingin akan menyebabkan respon imun yang rendah jika dibandingkan dengan dipelihara pada air bertemperatur lebih hangat (Nikoskelainen et al., 2004). Kisaran pH air media pemeliharaan menunjukkan nilai yang relatif stabil dan masih berada pada kondisi layak untuk pemeliharaan ikan. Menurut (Boyd, 1988), nilai kisaran $\mathrm{pH}$ untuk pemeliharaan ikan adalah 6-9. Hasil pengukuran untuk nilai oksigen terlarut memiliki kisaran antara $6,0-8,0$. Kondisi tersebut masih berada pada kondisi baik dan mendukung untuk pemeliharaan ikan. Hal tersebut sesuai dengan PP No 82 Tahun 2001 tentang Pengelolaan Kualitas Air dan Pengendalian Pencemaran air yang menjelaskan bahwa untuk ikan yang termasuk ke dalam famili Cyprinadae batas minamal kadar oksigen terlarut adalah 4 .

\section{SIMPULAN}

Pemaparan limbah cair batik hasil biosorpsi terhadap Ikan Mas berpengaruh terhadap penurunan nilai hematokrit dan konsentrasi limbah cair batik hasil biosorpsi yang paling berpengaruh adalah $75 \%$ dari nilai $\mathrm{LC}_{50}$ sebesar 3,96\% v.v ${ }^{-1}$. Penurunan nilai hematokrit seiring dengan penambahan konsentrasi limbah cair batik hasil biosorpsi.

\section{UCAPAN TERIMA KASIH}

Ucapan terimakasih disampaikan kepada Lembaga Penelitian dan Pengabdian kepada Masyarakat Universitas Jenderal Soedirman atas pembiayaan penelitian melalui Skim Peningkatan Kompetensi dengan Nomor Kontrak 2461/UN23.14/PN/2018.

\section{DAFTAR REFERENSI}

Boyd, C.E., 1988. Water Quality in Warmwater Fish Pond. Faurth Printing. Auburn Aniversity Agricultural Experiment Station: Alabama, US.

Casarett, L.J. \& Klaassen, C.D., 2008. Casarett and Doull's Toxicology: The Basic Science of Poisons. New York: McGraw-Hill Medical.

Flajšhans, M. \& Hulata, G., 2007. Genetic Impact of Aquaculture Activities on Native Populations: 
Common Carp-Cyprinus carpio. Framework plan of the European Commission: Eropa.

Hrubec, T.C. \& Smith, S.A., 2010. Hematology of Fishes. In Weiss DJ \& Wardrop KJ (Eds.). Veterinary Hematology 6rd Edition. New Jersey: Wiley-Blackwell Ltd.

Joshi, N.C., 2017. A Brief Discussion on Biosorption and Biosorption Technology. Journal of Pharmaceutical, Chemical and Biological Sciences, 5(4), pp.330-336.

Lestari, S., Sudarmadji, S.D. Tandjung, S.D. \& Santosa, S.J., 2015. Kajian Kualitas Air Kali Wangan yang Tercemar Limbah Cair Batik. Prosiding. Seminar Nasional Pengelolaan Sumberdaya Alam dan Lingkungan, pp:553556 ISBN:978-602-73313-0-3. ---., 2017. Lethal Toxicity of Batik Waste Water Bio-Sorption Result in Tilapia. Advanced Science Letter, 23, pp. 2611-2613. ., 2018. Biosorpsi Krom Pada Limbah Cair Batik Menggunakan Biosorben dalam Kantung Teh Celup dan Uji Toksisitasnya terhadap Ikan Nila (Oreochromis niloticus Linnaeus, 1758). Disertasi. Sekolah Pascasarjana, Universitas Gadjah Mada, Yogyakarta.

-., Dewi, R.S., Wibowo, E.S. \& Atang. 2019. Biosorption $\mathrm{Cr}$ and Dye Using Biosorbent Modified Tea Bag. Journal of Microbal Systematics and Biotechnology, 1(1), pp. 38-43.

Nikoskelainen, S., Bylund, G. \& Lilius, E.M., 2004. Effect of Environmental Temperature on Rainbow Trout (Oncorhynchus mykiss) Innate Immunity. Developmental and Comparative Immunology, 28(6), pp.58-592.

Nordberg, G.F., Bruce, A.F. \& Monica, N., 2015. Handbook on the Toxicology of Metals. Fourth Edition. United Kingdom: Elsevier Science, Academic Press.
Okuo, J. M., Sanni, S. B. \& Aigbedio, S., 2006. Selective Biosoption of Heavy Metal Ions from Aqueous Solutions by Pre-Treated Negerian Fresh Water Algae. Trends in Applied Sciences Research, 1(1), pp.83-90.

Prayogo, N.A., Atik, H., Asrul, S.S. \& Yunasfi., 2016. Uji Toksisitas Letal dan Subletal Logam Berat Merkuri (Hg) Terhadap Ikan Nilem (Osteochilus hasselti). Omni Akuatika, 12(1), pp.86-94.

Sari, Y., Djong, H.T. \& Resti, R., 2016. Gambaran Darah Katak Fejervarya limnocharis di Lahan Pertanian yang Menggunakan Pestisida di Sumatera Barat. Biogenesis, 4(2), pp.115-121.

Tripathi, N.K., Latimer, K.S. \& Burnley, V.V., 2004. Hematologic Reference Intervals for Koi (Cyprinus carpio), Including Blood Cell Morphology, Cytochemistry, and Ultrastructure. Vet. Clin. Pathol. 33(2), pp.74-83.

Uttamrao, B.M., Jaiswal, N.R. \& Kadam, M.S., 2017. Hematological Profile of Common Carp (Cyprinus carpio) Under Sublethal Effect of Trivalent Chromium. International, Res. J. of Science and Engineering, 5(6), pp.104-108.

Velma, V., Vutukuru, S.S. \& Tchounwou, P.B., 2009. Ecotoxicology of Hexavalent Chromium in Freshwater Fish: A Critical Review. Rev Environ Health, 24(2), pp.129145.

Zaki, M.S., Moustafa, S., Rashad, H. \& Sharaf, N., 2009. Assessment of Hazardous Effect of Pollution on Oreochromis niloticus Including Hematological, Biochemical \& Immunological Parameters. J. Agricult. Environ. Sci., 3(1), pp.91-95. 